\title{
A SIMPLIFIED INVENTORY APPROACH FOR ESTIMATING CARBON IN COARSE WOODY DEBRIS IN HIGH-BIOMASS FORESTS
}

\author{
by Julia Sohn, Chris McElhinny, Simon Grove, Eva Hilbig and Jürgen Bauhus
}

\author{
(with four tables and three text-figures)
}

\begin{abstract}
Sohn, J., McElhinny, C., Grove, S., Hilbig, E. \& Bauhus, J. 2013 (17:xii): A simplified inventory approach for estimating carbon in coarse woody debris in high-biomass forests. Papers and Proceedings of the Royal Society of Tasmania 147: 15-23. https://doi.org/10.26749/rstpp.147.15 ISSN 0080- 4703. Albert-Ludwigs-University Freiburg, Chair of Silviculture, Tennenbacherstr. 4, 79106 Freiburg, Germany (JS, EH, JB*); Australian National University, College of Science, The Fenner School of Environment and Society, Forestry Building 48, Linnaeus Way, Canberra ACT 0200, Australia (CM); Forestry Tasmania, 79 Melville Street, Hobart TAS 7000, Australia. Current address: Rosny Collections and Research Facility, Tasmanian Museum and Art Gallery, Rosny, TAS 7018, Australia (SG). *Author for correspondence. Email: juergen.bauhus@waldbau.uni-freiburg.de

Forests carrying large quantities of live and dead wood are important carbon $(\mathrm{C})$ stores. Here, we investigate how the inventory of coarse woody debris (CWD) and its embedded C (CWD-C) may be designed efficiently at the scale of logs, plots, and the landscape in Tasmanian tall Eucalyptus obliqua forests, which have very high levels of CWD (here 375-1085 $\mathrm{m}^{3} \mathrm{ha}^{-1}$ ). From a set of 12 sites representing different times since disturbance, a thorough census of dead wood $>10 \mathrm{~cm}$ in diameter was carried out at five sites using a fixed-plot $(50 \times 50 \mathrm{~m})$ approach. This showed that $90 \%$ of the volume can be captured by recording only CWD logs $>40 \mathrm{~cm}$ in diameter. Based on this approach and on the known density and $\mathrm{C}$ content of five different decay-classes, volume, mass, and CWD-C was determined for all 12 sites. To obtain an accurate estimate of CWD-C at the landscape scale, it was found to be sufficient to allocate entire individual logs to single decay-classes and to use one global value for $\mathrm{C}$ content instead of decay-class-specific values. The most decayed logs, which are difficult to measure, could be ignored. However, at the plot level, no relationships were found between CWD mass and either standing or downed CWD or standing-tree biomass, limiting the utility of these proxies for assessing CWD volume.
\end{abstract}

Key Words: Coarse woody debris, monitoring, logs, decay-class, carbon.

\section{INTRODUCTION}

Coarse woody debris (CWD) comprises all aboveground dead woody biomass that exceeds certain thresholds in diameter and length. It includes standing (snags or stags), and downed boles (logs) and branches of dying and dead trees. Forests characterised by a high abundance and continuity of CWD are important carbon (C) stores and the CWD is important for a range of ecosystem functions. Research conducted over the last three decades has demonstrated that standing and downed CWD is a key structural and functional element of forest ecosystems (e.g., Harmon et al. 1986, Spies et al. 1988, Franklin etal. 2002, Siitonen 2001, Stewart \& Burrows 1994, Carmona et al. 2002, Lindenmayer \& Franklin 2002).

Increasing awareness of the significant role that dead wood plays for ecosystem functioning has led to the consideration of CWD in sustainable forest management worldwide (Bauhus et al. 2009, Hunter 1994, Grove 2002, Ranius et al. 2003, Lindenmayer et al. 2006). A common objective of the management of CWD is to maintain its spatial and temporal arrangement in a manner that mimics patterns caused by natural disturbance and stand development and provides for a continuity of habitat conditions (Franklin et al. 2002, Keeton 2006). To assign local benchmarks for CWD levels for certain forest types and to manage this pool, the natural variation of CWD attributes needs to be known and monitored. Inventories of CWD are also important for reporting of C storage in forests (Gough 2007).

In regions dominated by forests with relatively low amounts of CWD - for example boreal forests, forests of drier regions, or evergreen tropical forests - a full census of all types of CWD can be done relatively quickly using plot-based or line-intersect methods (e.g., Karjalainen \& Kuuluvainen 2002, Woldendorp et al. 2004, Grove 2001).
In contrast, in forest regions characterised by very high quantities of dead wood, inventory of all pieces of CWD across large areas or along numerous long lines are extremely time-consuming and expensive, and therefore impractical in most situations.

The main aim of this study was to examine whether it was possible to simplify the plot-based inventory of CWD and associated $\mathrm{C}$ in forests which carry large amounts of dead wood such as the Tasmanian tall wet eucalypt forests (Woldendorp et al. 2004) by identifying the CWD attributes that should be measured and those that may not have to be quantified. In particular, the study asked whether for estimating CWD volume, biomass and C content:

- it is possible to concentrate the inventory on larger CWD piece;

- it is sufficient to allocate individual logs to the dominating (in terms of volume) decay-class of that log to calculate its average mass and $\mathrm{C}$ density;

- one needs to also capture the most advanced decay stage, which is always difficult to quantify in terms of volume and mass and

- volumes of both standing living and dead trees available from many inventories may be used to predict the volume of downed logs.

To answer these questions, we first quantified all types of CWD with a diameter greater than $10 \mathrm{~cm}$ in five 0.25 ha plots located in tall wet Eucalyptus obliqua (L'Hérit.) stands of different disturbance history and age. We investigated the frequency of a range of CWD attributes and the relationships among them in order to identify key parameters and to determine appropriate minimum diameter-thresholds. Second, these results were applied for sampling seven additional E. obliqua stands, which were comparable in age and origin to those assessed before, in 
order to capture the variation in CWD and C more widely in the same landscape.

\section{METHODS}

\section{Study region and forest dynamics}

The study was conducted at the Warra Long Term Ecological Research (LTER) site (Brown et al. 2001) in southern Tasmania, Australia (latitude $43^{\circ} \mathrm{S}$, longitude $147^{\circ} \mathrm{E}$ ). The climate at Warra is temperate maritime with a mean annual temperature of $7.9^{\circ} \mathrm{C}$, and an annual precipitation of $1477 \mathrm{~mm}$. The region is characterised by mountainous terrain with peaks up to $1200 \mathrm{~m}$ above sea level. The geology is Jurassic dolerite, which produces fertile, deep clay soils (Turner et al. 2007).

The vegetation of this region is southern cool temperate wet forest. Wildfires, with return intervals of 100-400 years, lead to the predominance of tall wet E. obliqua forests. This forest type is characterised by a tall ( $>30$ $\mathrm{m}$ ), open (projective foliage cover 30-70 \%) eucalypt overstorey, dominated by E. obliqua and some admixed $E$. regnans (F. Muell) or E. delegatensis (R. Baker). On fertile, protected sites, old trees reach more than $55 \mathrm{~m}$ in height, in rare cases over 80 or $90 \mathrm{~m}$ (Hickey et al. 2000). The understorey can be variable in density and composition, and contains numerous sclerophyll species such as Acacia spp., Anopterus glandulosus Labill., Clematis aristata R. Br. ex Ker Gawler, Cyathodes glauca Labill., Monotoca glauca (Labill.) Druce, Nematolepis squamea (Labill.) Paul G. Wilson, Olearia argophylla (Labill.) Benth., Pimelea linifolia linifolia Smith, Pomaderris apetala Labill. and Tasmannia lanceolata (Poiret) A.C. Smith.

If fire intervals exceed 100 years, mixed forests with tall eucalypt emergents above a rainforest midstorey containing (Nothofagus cunninghamii (Hook.) Oersted, Atherosperma moschatum Labill., Eucryphia lucida (Labill.) Baill. and Phyllocladus aspleniifolius (Labill.) Rich. ex Hook. f.) will replace pure eucalypt stands. In the absence of fires for more than 350-400 years, the flammable eucalypt overstorey dies out and a much less flammable rainforest persists (Wells \& Hickey 2005)

\section{Study plots}

Measurements were carried out in twelve permanent plots, which had been established as part of a "wildfire chronosequence project" in the Warra region (Turner $e t$ al.

TABLE 1

Origin, density and composition of the twelve plots of the Warra wildfire chronosequence project measured in this study

\begin{tabular}{|c|c|c|c|c|}
\hline Plot & Origin & $\begin{array}{c}\text { Basal area }\left(\mathrm{m}^{2}\right. \\
\left.\mathrm{ha}^{-1}\right) \text { of living } \\
\text { trees }>10 \mathrm{~cm}\end{array}$ & $\begin{array}{l}\text { Proportion of total basal area by genus } \\
\qquad(\%)^{1}\end{array}$ & $\begin{array}{l}\text { CWD volume }\left(\mathrm{m}^{3} \mathrm{ha}\right) \text { of logs } \\
\text { and stags }>40 \mathrm{~cm} \text { diameter } \\
(\text { logs and stags }>10 \mathrm{~cm})\end{array}$ \\
\hline OGS & $\begin{array}{l}\text { Undated wildfire } \\
\text { before } 1898\end{array}$ & 117.3 & $\begin{array}{l}\text { Eucalyptus sp. (40), Nothofagus } \\
\text { cunninghamii (20), Atherosperma } \\
\text { moschatum (15), Dicksonia antarctica (20) }\end{array}$ & $851(1005)$ \\
\hline OGN & & 126.1 & $\begin{array}{l}\text { Eucalyptus sp. (75), Eucryphia lucida (10), } \\
\text { Phyllocladus aspleniifolius (5) }\end{array}$ & 922 \\
\hline $1898 S$ & $\begin{array}{l}\text { Wildfire in } 1898 \text { and } \\
\text { partly burned in } 1934\end{array}$ & 91.6 & $\begin{array}{l}\text { Eucalyptus sp. (75), Pomaderris apetala } \\
\text { (15) }\end{array}$ & $299(351)$ \\
\hline $1898 \mathrm{~N}$ & & 71.2 & $\begin{array}{l}\text { Eucalyptus sp. (80), Pomaderris apetala } \\
\text { (15) }\end{array}$ & 806 \\
\hline $1934 S$ & Wildfire in 1934 & 118.9 & $\begin{array}{l}\text { Eucalyptus sp. (70), Dicksonia antarctica } \\
\text { (15) }\end{array}$ & $477(558)$ \\
\hline $1934 \mathrm{~N}$ & & 71.3 & $\begin{array}{l}\text { Eucalyptus sp. (85), Pomaderris apetala } \\
\text { (10) }\end{array}$ & 998 \\
\hline $1966 S$ & Wildfire in 1966 & 44.0 & Eucalyptus sp. (95) & $464(559)$ \\
\hline $1966 \mathrm{~N}$ & & 51.4 & $\begin{array}{l}\text { Eucalyptus sp. (50), Acacia dealbata (10), } \\
\text { Dicksonia antarctica (20), Pomaderris } \\
\text { apetala (20) }\end{array}$ & 1410 \\
\hline $1967 \mathrm{CS}$ & $\begin{array}{l}\text { Clearfell-burn-sow } \\
\text { in } 1967\end{array}$ & 46.2 & Eucalyptus sp. (85), Acacia dealbata (5) & $1001(1176)$ \\
\hline $1967 \mathrm{CN}$ & & 59.3 & Eucalyptus sp. (90), Acacia dealbata (5) & 1006 \\
\hline 2001CS & $\begin{array}{l}\text { Clearfell-burn-sow in } \\
2001 \text { resp. } 2003\end{array}$ & 0.0 & $\mathrm{~N} / \mathrm{a}$ & 403 \\
\hline $2003 \mathrm{CN}$ & & 0.2 & $\mathrm{~N} / \mathrm{a}$ & 680 \\
\hline
\end{tabular}

The fourth column shows the proportion (rounded to nearest $5 \%$ ) of total basal area for each tree genus contributing at least $5 \%$. Plots in bold letters (first column) belonged to the first measuring campaign (= full-census). For all twelve plots, CWD volume of logs and stags $>40 \mathrm{~cm}$ is shown (last column). Additionally, for the five full-census plots, CWD volume of logs and stags $>10 \mathrm{~cm}$ is depicted (last column number in brackets). $\mathrm{S}=$ south facing, $\mathrm{N}=$ north facing slopes, $\mathrm{OG}=$ undated old-growth. 
2007) (table 1). Sites were selected to represent comparable environments. They were situated 120-280 m above sea level on mid-slopes. Eight of the twelve plots were wildfire-derived, with four being located on south-facing $(S)$ and four on north-facing (N) slopes (table 1, Turner et al. 2007). These eight sites had no history of active forest management and represented different-aged ("regrowth") stands that initiated following wildfire disturbance in 1966 (referred to as 1966S and $1966 \mathrm{~N}$ ), 1934 (referred to as 1934 S and $1934 \mathrm{~N}$ ), 1898 (referred to as $1898 \mathrm{~S}$ and $1898 \mathrm{~N}$ ), and an undated fire before 1898 (referred to as old-growth = OGS and OGN). Even though the 1898 stands are ostensibly derived from a wildfire in 1898, elements of their stand structure and tree species composition indicate that they were also partially burnt in 1934.

The remaining four sites were stands regenerated following clearfelling and a regeneration burn and sowing of eucalypts. Again two were located on south-facing and two on north-facing slopes. Two of these plots were harvested in 1966 (referred to as 1966CS and 1966CN), one in 2001 (referred to as 2001CS) and the fourth in 2003 (referred to as 2003CN) (Turner et al. 2007).

\section{Field measurements and calculation of secondary attributes}

Each plot comprised a $50 \times 50 \mathrm{~m}(0.25 \mathrm{ha})$ quadrat, divided into 25 subplots of $10 \times 10 \mathrm{~m}$ (Turner et al. 2007). In the first measuring campaign, each piece of standing and downed dead wood $>10 \mathrm{~cm}$ in diameter and $>1 \mathrm{~m}$ in length present in the plot was assessed at five sites (table 1 plots in bold letters). Based on the results from the first measuring campaign, the original inventory protocol was modified so that in the seven remaining plots only logs larger than 40 $\mathrm{cm}$ diameter were measured during a second field campaign. However, for standing dead wood, we still used the $10 \mathrm{~cm}$ diameter threshold.

The following measurements were made: CWD type (snag/log/branch; the latter only if not attached to boles any longer, or if unclear "unidentified"), species (if identifiable), horizontal (width) and vertical (depth) diameter at each end of the piece; length; decay-class (using a five-class system described in Grove et al. (2009). For the logs of the second campaign, multiple decay-classes were still recorded for each piece of dead wood, since it was not known what effect a simplified reporting of one decay-class per log would have had on mass and $\mathrm{C}$ content, which can vary considerably with decay-class and rot type in these forests (Grove et al. 2009).

For standing CWD, only diameter at breast height $(1.3 \mathrm{~m})$ and total height were recorded. These attributes represented the most frequently measured parameters in previous studies of CWD (e.g,. Spies et al. 1988, Stewart \& Burrows 1994, Harmon \& Sexton 1996, McKenny \& Kirkpatrick 1999, Carmona et al. 2002, Pedlar et al. 2002, McElhinny et al. 2006).

Measurements took place at the level of log-segments, in which pieces of CWD were divided whenever they showed a change in decay-class or crossed a subplot boundary. The following secondary attributes were derived from the directly measured attributes:

Log or branch volume V $\left(\mathrm{m}^{3}\right)$ was derived using Smalian's formula as suggested by Harmon et al. (1986):

$$
V=\left(\frac{\left(a_{1}+a_{2}\right)}{2}\right) \times l
$$

where $a_{1}$ and $a_{2}$ are the cross-sectional areas $\left(\mathrm{m}^{2}\right)$ of each end and $l$ is the length $(\mathrm{m})$ of the CWD piece or sub-segment.

Snag volume $V_{s}\left(\mathrm{~m}^{3}\right)$ was derived using a taper function for E. obliqua (Private Forests Tasmania 2001):

$$
V_{s}=\frac{0.2 \times d b h^{2} \times h}{10000}
$$

where $d b h$ is the diameter at breast height $(\mathrm{cm})$ and $h$ the height (m).

Decay-class diversity $\left(D^{*}\right)$ within each log was derived using the Shannon-Weaver Index (Krebs 1989):

$$
D^{*}=-\sum_{i=1}^{S} p_{i} \ln p_{i}
$$

where $S$ is the number of decay-classes present in a log, and $p_{i}$ the proportion of volume in a given decay-class.

To calculate the carbon stock in CWD of each plot, we calculated first the CWD volume of each decay-class separately. Volumes in each decay-class were multiplied by values of CWD density in the different decay-classes of CWD, which had been determined for this forest type $\left(\mathrm{DC} 1=495.25 \mathrm{~kg} \mathrm{~m}^{-3}, \mathrm{DC} 2=439.41 \mathrm{~kg} \mathrm{~m}^{-3}, \mathrm{DC} 3=\right.$ $378.96 \mathrm{~kg} \mathrm{~m}^{-3}$, DC4=291.67 $\mathrm{kg} \mathrm{m}^{-3}$, and DC5= 212.17 $\mathrm{kg} \mathrm{m}^{-3}$ ) (Grove et al. 2009). These values are based on the calculations of average distribution of rotten-wood types and associated densities for each decay-class (see Grove et al. 2009). The resulting values for biomass of logs in each of the five decay-classes were multiplied by 0.5 to yield the C-content of CWD. This simple conversion could be done as C-content of CWD biomass is generally about $50 \%$ and remains largely unaffected by decay-state in $E$. obliqua (Grove et al. 2009).

\section{Data analysis}

The measured and calculated attributes of log-segments were pooled for analyses at the scale of whole logs in order to detect relationships among attributes and variation among individual logs. Correlation matrices containing the measured and derived variables were used to identify possible relationships. Pearson correlation coefficients $(r)$ were used to assess correlations among all possible combinations of log attributes. R-values between 0.5 and 0.8 were considered to be moderately correlated, and $r$-values $>0.8$ to be highly correlated. To examine relationships for moderately and highly correlated variables further, regression analysis was used.

The effect of different minimum diameter-thresholds of logs measured (10 to $100 \mathrm{~cm}$ in $10 \mathrm{~cm}$ steps) on the proportions of the total number of logs and total CWD volume captured was assessed for the five full-census plots.

As recording decay-class composition of logs can be a relatively complex procedure and relies on subjective visual estimation of decay-classes of log segments, we investigated how this can be done more efficiently. First we examined the possible overestimation or underestimation of decay- 
class-specific CWD volume associated with assigning a single decay-class to individual logs instead of multiple decay-classes as was done during our first measuring campaign. This was done for each of the five full-census plots and separately for all logs and for small logs only ( $<40 \mathrm{~cm}$ diameter).

Next, we checked the accuracy of carbon calculations when using only one average value for converting volume into biomass density instead of decay-class specific values for density of CWD. For this purpose, CWD-C in each of the twelve plots (calculated as described above) was compared with a value obtained by multiplying plot volume by the C-density of decay-class 3 , which was the most abundant with regards to volume.

\section{Determination of living stem biomass}

In a preceding inventory, the $\mathrm{DBH}$ of all live stems $>10$ $\mathrm{cm}$ DBH (diameter at breast height above bark) had been recorded to the nearest $\mathrm{cm}$, and the species determined. Height to top of crown was measured for a representative sample of trees for each major species. These height data were used to assign mean dominant height values for each species in each plot. We used a package of programs (Farm Forestry Toolbox, Private Forests Tasmania 2001) to calculate plot-level basal area and total stem volume.

\section{RESULTS}

\section{Monitoring at the scale of CWD pieces}

The volume of total (downed and standing) CWD $>10 \mathrm{~cm}$ ranged between 350 and $1175 \mathrm{~m}^{3} \mathrm{ha}^{-1}$ among the first five plots (table 1 , right column numbers in parentheses). The bulk of this $(87 \%)$ occurred as downed rather than standing CWD (13\%). Branches comprised about $25 \%$ of all measured pieces of CWD but contained only about $5 \%$ of the total
CWD volume (table 2). Increasing the minimum diameterthresholds for inventory of CWD showed that the number of pieces to be measured dropped off much more rapidly than the volume of CWD captured at the same time (fig. 1).

Logs had a significantly higher decay-class diversity index than branches (table 2$)$. There were significant $(\mathrm{p}<0.01)$, although weak, correlations between decay-class diversity and measures of CWD size. The strongest correlation $(r=0.41$, results not shown) was between decay-class diversity and CWD length, indicating that longer pieces of CWD were more likely to contain sections in different decay-classes. The correlations between decay-class diversity and CWD volume and CWD mean diameter were weak $(r=0.29$ and $r=0.24$, respectively, results not shown). Ninety-two percent of CWD pieces showed no change in decay-class along their length; for logs $<40 \mathrm{~cm}$ mean diameter this value increased to $94 \%$.

Assigning entire logs only to the volumetrically dominant decay-class instead of multiple classes led to deviations of up to $15 \%$ of CWD volume at the level of individual plots $(50 \times 50 \mathrm{~m})$ (decay-class 3 in the old-growth stand, table 3a). However, if only considering $\operatorname{logs}<40 \mathrm{~cm}$ for single decay-class classifications while still using multiple decay-classes for logs $>40 \mathrm{~cm}$, the maximum error was considerably smaller at only $2.7 \%$ (decay-class 4 in the 1967 clearfelling plot, table 3b). The deviations caused by assigning only on decay class to logs were not systematic.

\section{Monitoring at plot- and landscape-scales}

During the second measurement campaign, attributes of $255 \operatorname{logs}$ with a mean diameter $>40 \mathrm{~cm}$ were measured in seven additional plots of wet E. obliqua forest (table 1, plot names in bold letters). The following results are based on analyses of attributes of these logs and the additional 128 $\log s>40 \mathrm{~cm}$ diameter which had been recorded in the five plots of the first, intensive measurement campaign.

TABLE 2

Mean and range (in brackets) of diameter, length, volume, and decay-class diversity index for 848 logs and 248 branches and the number of plant species (ferns and vascular plants) present on them in five Eucalyptus obliqua stands ranging in age from 41 to $>110 \mathrm{yrs}$

\begin{tabular}{|c|c|c|}
\hline Attribute & Logs & Branches \\
\hline Diameter $(\mathrm{cm})$ & $25.5^{1}\left(5.7^{2}-213.8\right)$ & $20.5^{1}(8.4-58.1)$ \\
\hline Length (m) & $4.2^{1}(1.0-56.6)$ & $3.2^{1}(1.0-27.0)$ \\
\hline Volume $\left(\mathrm{m}^{3}\right)$ & $0.89^{1}(0.004-52.4)$ & $0.15^{1}(0.007-2.2)$ \\
\hline Decay-class diversity index & $0.05^{1}(0-1.05)$ & $0.03^{1}(0-0.70)$ \\
\hline Number of ferns and vascular plant species & $1.3^{1}(0-11)$ & $0.1^{1}(0-7)$ \\
\hline Proportion of total CWD volume $(\%)^{3}$ & 94.8 & 4.8 \\
\hline Proportion of total number of CWD pieces (\%) & 75 & 25 \\
\hline \multicolumn{3}{|c|}{$\begin{array}{l}{ }^{1} \text { indicates a significant difference between values }(\mathrm{P}<0.05) \text {. } \\
{ }^{2} \text { Value could be }<10 \mathrm{~cm} \text { because the CWD threshold of } 10 \mathrm{~cm} \text { applied only for measuring width and not for depth. Diameter } \\
\text { was calculated as the geometric mean of width and depth. } \\
{ }^{3} \text { The proportions of } \log \text { and branch volumes amount to less than } 100 \% \text { as some pieces of CWD could not be classified as a } \\
\text { log or a branch. }\end{array}$} \\
\hline
\end{tabular}




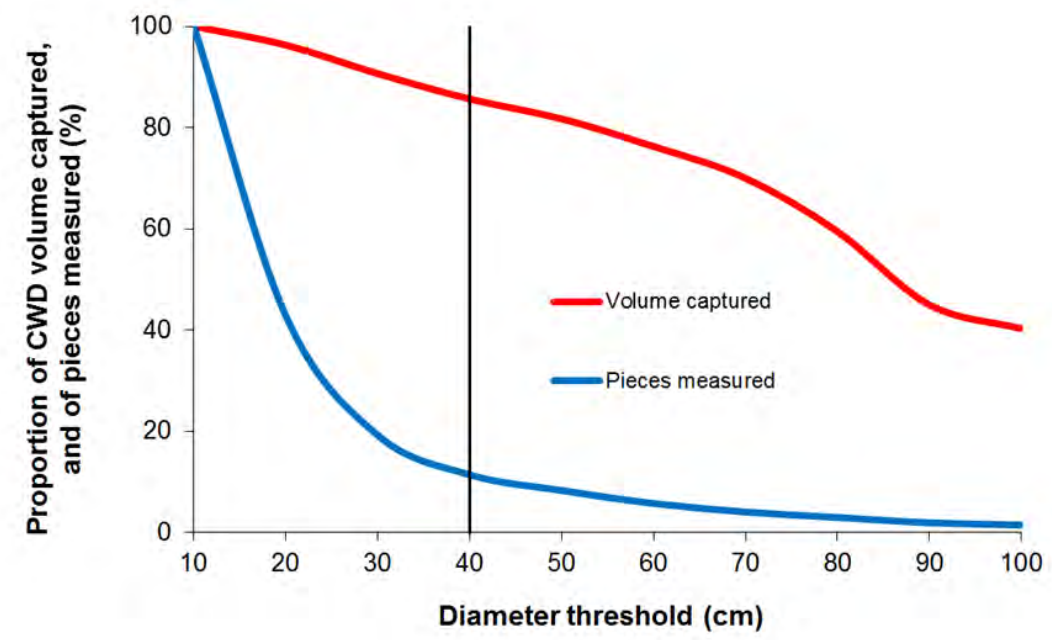

FIG. 1 - Proportion of total number of logs and branches measured and proportion of total CWD volume captured for different diameter measurement-thresholds. The grey vertical line displays a diameter threshold of $40 \mathrm{~cm}$, which was used during our second measuring campaign. ( $N=1096$, which includes all logs and branches $>10 \mathrm{~cm}$ measured in the five plots of the first campaign.)

TABLE 3

Over- or underestimation of percentage of CWD volume in each decay-class per plot, when assigning a single decay-class rather than multiple decay-classes to (a) all logs, and (b) logs with a diameter of $<40 \mathrm{~cm}$ only. For a given piece of CWD the decay-class containing the greatest proportion of volume was allocated to that piece.

\begin{tabular}{lccccc}
\hline Plot & \multicolumn{5}{c}{ Deviation (\%) from real CWD volume in decay-class } \\
& $\mathbf{1}$ & $\mathbf{2}$ & $\mathbf{3}$ & $\mathbf{4}$ & $\mathbf{5}$ \\
\hline (a) All logs & & & & & \\
OGS & 0.0 & -0.0 & 15.0 & -8.1 & -6.9 \\
$1898 S$ & 0.0 & -0.1 & 3.0 & 1.1 & -4.1 \\
$1934 S$ & 0.7 & 0.1 & -2.6 & -0.9 & 3.4 \\
$1966 S$ & 0.0 & 10.4 & -12.6 & 2.5 & -0.3 \\
1967 CS & 0.0 & -4.0 & 7.6 & -3.2 & -0.4 \\
(b) Logs $<40$ cm diameter only & & & & \\
OGS & 0.0 & -0.2 & -0.5 & 2.4 & -1.7 \\
$1898 S$ & 0.0 & -0.3 & 1.5 & 0.6 & -1.8 \\
$1934 S$ & 0.4 & 0.7 & 1.1 & -2.1 & 0.0 \\
$1966 S$ & 0.0 & -1.2 & 2.4 & -0.6 & -0.6 \\
1967 CS & 0.0 & -0.1 & -2.7 & 2.7 & 0.0 \\
\hline
\end{tabular}

The proportion of log volume in different decay-classes varied considerably. Relatively small values were measured in three out of five decay-classes $(0.3 \%$ in DC1, ca. $6 \%$ in DC5, and ca. $8 \%$ in DC 2, fig. 2), while the remaining two decay-classes accounted for the bulk of log volume with ca. $59 \%$ of CWD volume contained in DC3 and $27 \%$ in DC4 (fig. 2). We now analysed the effect of assigning a single instead of multiple decay-classes to individual logs for all logs $(\mathrm{N}=383)$ across twelve plots $(=3 \mathrm{ha})$. This led to only minor deviations $(-2.6 \%$ to $+3.3 \%)$ from actual CWD volume per ha within different decay-classes at this larger spatial scale (fig. 2).

The estimated amount of plot-based C present in CWD logs $>40 \mathrm{~cm}$ ranged from 52.9 to $183.0 \mathrm{Mg} \mathrm{ha}^{-1}$ and was on average $119.4 \mathrm{Mg} \mathrm{ha}^{-1}$ across the twelve plots (table 4). To explore further simplifications, we investigated the 


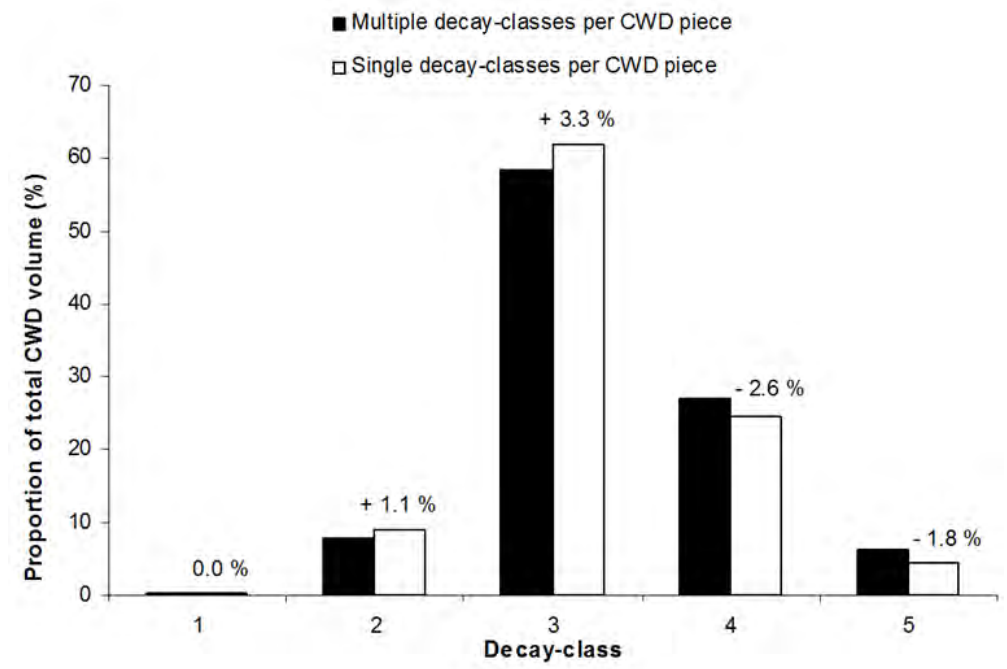

FIG. 2 - Proportion of total CWD volume per ha in different decay-classes, if assigning logs to multiple or single decay-classes. For a given piece of CWD the decay-class containing the greatest proportion of volume was allocated to that piece. Values refer to logs $>40 \mathrm{~cm}$ which were measured in twelve Eucalyptus obliqua stands. For each decay-class the over-or underestimation of actual volume is presented as percent error (\%), $N=383$.

TABLE 4

Carbon mass $\left(\mathrm{Mg} \mathrm{ha}^{-1}\right)$ of large logs $(>40 \mathrm{~cm}$ mean diameter) in twelve plots of tall wet Eucalyptus obliqua forests and mean across all plots, and deviations (\%) from these values if only one average value for wood density is used, or if logs of the most advanced decay-class (DC5) are disregarded.

\begin{tabular}{lccc}
\hline Plots & $\begin{array}{c}\mathbf{C}\left(\mathbf{M g ~ h a}^{-1}\right) \text { in logs } \\
\mathbf{4 0 ~} \mathbf{~ c m} \text { mean diameter }\end{array}$ & $\begin{array}{c}\text { Deviations if considering } \\
\text { density of } \mathbf{D C 3} \text { only } \mathbf{( \% )}\end{array}$ & $\begin{array}{c}\text { Underestimations if disregard- } \\
\text { ing } \mathbf{D C 5} \text { in inventory (\%) }\end{array}$ \\
\hline OGS & 133.5 & 5.2 & -12.0 \\
OGN & 160.9 & 4.1 & -8.6 \\
$1898 \mathrm{~S}$ & 52.9 & 2.2 & -4.6 \\
$1898 \mathrm{~N}$ & 142.8 & 3.1 & -9.9 \\
$1934 \mathrm{~S}$ & 88.7 & -2.2 & -4.5 \\
$1934 \mathrm{~N}$ & 117.8 & -1.4 & -7.0 \\
$1966 \mathrm{~S}$ & 60.1 & -5.4 & -0.7 \\
$1966 \mathrm{~N}$ & 152.1 & -1.7 & -2.1 \\
$1967 \mathrm{CS}$ & 183.0 & -3.6 & -0.3 \\
$1967 \mathrm{CN}$ & 139.8 & -3.7 & -0.2 \\
$2001 \mathrm{CS}$ & 67.1 & -9.1 & -5.4 \\
$2003 \mathrm{CN}$ & 134.0 & -7.5 & 0.0 \\
\hline Mean of all plots & 119.4 & -1.3 & -4.7 \\
\hline
\end{tabular}


effect of using only one average wood density — that of the most abundant decay-class (DC 3) — instead of five different decay-class-specific values for calculating CWD-C. This approach led to deviations between -9.1 and $+5.2 \%$ for individual plots (table 4). However, if we regard the plots as independent samples for the landscape dominated by this forest type, the total error would be small $(-1.3$ $\%)$ at the landscape scale (table 4, last row). An additional analysis showed that ignoring logs of the most advanced decay-class (DC5) during field measurements would lead to relatively small underestimations $(<5 \%)$ of total CWD-C at the landscape scale (table 4).

The assessment of the potential to predict CWD mass from information that can be remotely sensed showed that no correlation could be detected between the stem volume of live trees and the CWD volume across the twelve plots (fig. 3, r=-0.009, $\mathrm{N}=12$ ).

\section{DISCUSSION}

\section{Implications for monitoring at the scale of logs}

The results of the full census indicated that 95\% of CWD volume in these forests is in logs, and that large logs account for the bulk of this (table 2, fig. 1). Therefore, the number of pieces to be measured can be reduced drastically with little underestimation of the total CWD volume (fig. 1). Based on our results, the exclusion of logs smaller than 40 $\mathrm{cm}$ in diameter from inventory means that the remaining number of logs to be measured would amount only to ca. $10 \%$ of all logs, whilst still capturing ca. $90 \%$ of the total CWD volume.

However, when considering a diameter threshold for monitoring CWD volume, mass, or carbon, it is important to consider that trees can develop internal hollows while they are alive (Williams \& Faunt 1997), as was the case for our study sites. These hollows or "pipes" in eucalypt stems must be subtracted from the true CWD volume or mass. If the average degree of piping in CWD is known, then a diameter threshold can be used to compensate for the overestimation of volume induced by piping. Working in the same study-area, Stamm (2006) reported that E. obliqua logs across all decay-classes have an average internal airspace equivalent to $20-30 \%$ of the original volume. Assuming that logs derived from other species show similar piping to E. obliqua, or, more realistically, that all larger-diameter logs in a typical stand are derived from E. obliqua, then selecting a diameter threshold of 50-70 cm would balance losses due to piping and yet would require only 5-10\% of logs to be measured (fig. 1). Obviously, these thresholds are not transferable and would have to be determined for other high biomass forests.

We found that for estimating total $\mathrm{C}$ and volume in CWD, branches and small logs did not need to be measured in these forests. However, this may not be appropriate for studies investigating other attributes and functions of CWD that are particularly associated with these types of CWD, e.g., the presence of certain saproxylic species (Grove 2002).

\section{Implications for inventorying CWD at the landscape scale}

Although assigning large logs to only one decay-class per log would lead to considerable errors for calculating CWD volume by decay-class at smaller spatial scales (i.e., the fixed-area plots), at the landscape scale this simplification resulted in accurate estimates of CWD volume distribution over decay-classes (fig. 2). Further, at the landscape scale, CWD-C mass was underestimated by only about $1 \%$ when using one average value of wood density instead of decayclass specific ones (table 4).

Using this approach for inventory of CWD-C in forests dominated by large, long logs would present a significant simplification as assigning log segments to different decayclasses is time-consuming and also a considerable source of error due to subjectivity during decay-class classifications.

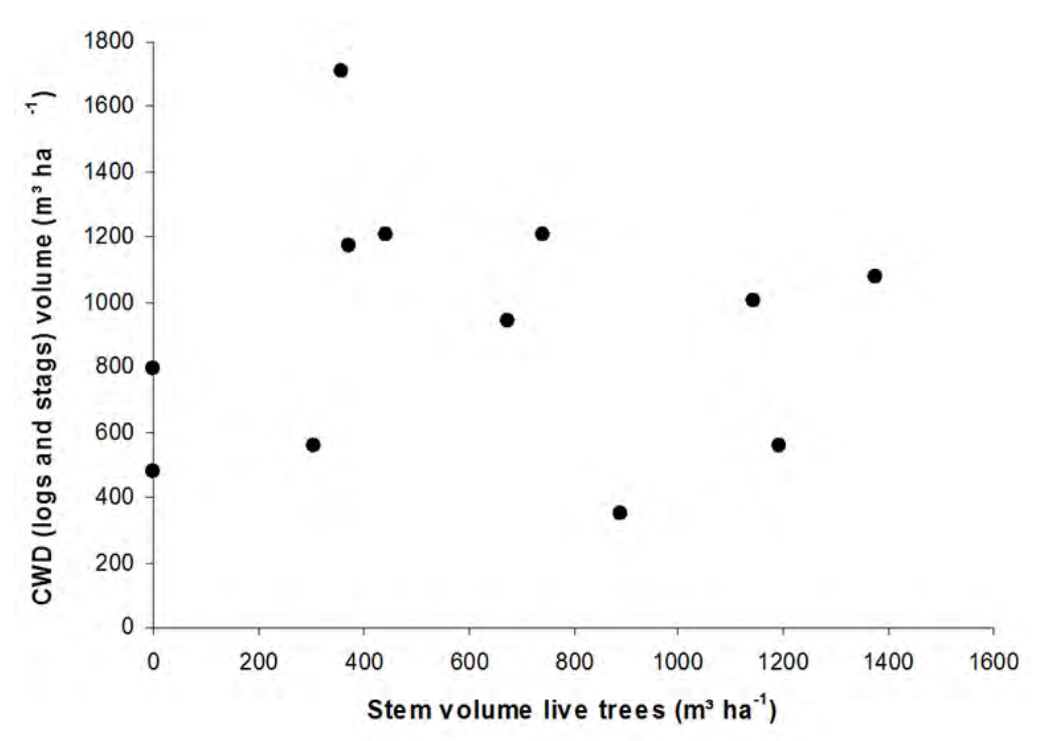

FIG. 3 - Relationship between CWD volume and stem volume of living trees in 12 different-aged Eucalyptus obliqua stands. 
However, this simplification may not be appropriate to estimate landscape-level CWD-C in situations with a more even distribution of CWD volumes across decay classes or where the decay-class with average $\mathrm{C}$ density is not also the most abundant, as was the case here with decay-class 3 .

Owing to the fact that decay-class 5 had the lowest carbon density $\left(0.15 \mathrm{Mg} \mathrm{m}^{-3}\right)$ and comprised only a low volume in these forests, not recording logs of decay-class 5 led to only small underestimation $(<5 \%)$ of actual carbon mass (table 4). Ignoring logs of DC5 may be especially promising for increasing efficiency of CWD assessments as logs belonging to this decay-stage are the most difficult to measure. Many of these logs have largely disintegrated, lost their original shape, and are often not visible beneath thick moss covers and root systems. However, the decision not to record this decay-class should be based on the assessment of its contribution to the total CWD volume, which may be higher in other forest types, i.e., temperate forests of Patagonia, Chile (Carmona et al. 2002).

Ranius \& Kindvall (2004) modelled the amount of CWD present in the landscape based on the relationship between the volumes of living trees and CWD for the mixed coniferous forests of boreal Sweden. Identifying this kind of relationship may be possible in forests in which the creation of dead wood is largely a function of selfthinning and small-scale disturbances. However, in the wet E. obliqua forests of southern Tasmania, biomass of living trees was not a good indicator for volume or mass of CWD probably due to the variable disturbance intensity in the wet E. obliqua forests and the longevity of both standing and downed trees. Therefore, it would be highly unlikely that amounts of CWD would ever be in equilibrium with living biomass. A low correlation between variables of downed CWD and living-tree characteristics was also found in boreal conservation forests in Eastern Finland (Pesonen et al. 2008). In addition, close relationships between living and dead woody biomass would also not agree with the temporal patterns of dead wood stocks following intensive disturbances as proposed by Harmon (2009).

\section{CONCLUSIONS}

Results from this study offer opportunities to increase the efficiency of CWD inventories for forests with high stocks of dead wood, as characteristically occur in forest ecosystems shaped by catastrophic disturbances and/or are characterised by slow decomposition rates. In addition to the tall wet eucalypt forest, this might apply also to coniferous forests in the Pacific Northwest of the US (e.g., Spies et al. 1988, Harmon et al. 1986) and the Nothofagus forests of New Zealand (Stewart \& Burrows 1994) and southern Chile (Carmona et al. 2002, Schlegel \& Donoso 2008).

For CWD biomass and carbon inventories in these types of forests, we recommend the following:

1. At any spatial scale:

- determine a minimum diameter-threshold to avoid sampling of many small CWD pieces.

2. For landscape surveys only:

- assign each CWD piece to a single decay-class and explore the use of a single density-value to convert volume to mass and $\mathrm{C}$ content,

- assess the effect of disregarding logs of the most advanced decay stage.

Our study was based on a plot-based approach, including a full census of CWD pieces with a diameter $>10 \mathrm{~cm}$ in each plot. This type of CWD inventory is often associated with regular grid- and plot-based forest inventories in which many other forest attributes are measured. Alternatively, sampling of downed CWD could be carried out with line intersect transects (Warren \& Olsen 1964, Van Wagner 1968), which have been shown to be more efficient in comparison with plot-based methods for Eucalyptus-dominated forests with a canopy cover of $>50 \%$ (Woldendorp et al. 2005). Our recommendations may be combined with the line intersect sampling approach. This might assist in determining variation of CWD attributes at the scale of forest landscapes, for which we are currently lacking information (e.g., Kennedy \& Spies 2007).

The recommendation to avoid measuring small diameter material CWD must be seen in the context of inventories of CWD volume and C. In fire-prone forest ecosystems, small-diameter woody litter may well be a valid focus of inventories because it contributes to the fuel hazard. The same may be said about special habitat that is provided by accumulations of small woody debris.

The results of our study emphasised the importance of recording downed CWD separately rather than using readily available data on vertical structure (.i,e. standing dead or living trees) as a proxy for estimating log volume. Owing to their tall, dense and evergreen canopies, the latter is scarcely assessable through remote sensing in tall wet eucalypt stands. However, in other forests, where density of canopy, sub-canopy and shrub and understorey layer permit, airborne laser-scanning maybe promising for the assessment of downed CWD (Naesset 2007, Pesonen et al. 2008).

\section{ACKNOWLEDGEMENTS}

\section{A Tribute to Chris McElhinny}

This contribution is dedicated to Chris McElhinny, Senior Lecturer in Forest Ecology and Silviculture, who died before this paper could be published. Chris was fascinated by the structure and complexity of forests, in particular by tall wet eucalypt forests, and he made important contributions to their analysis and sustainable management. His fascination for the topic, his creative analyses and his dedication to responsible solutions for the management of Australia's forests inspired his colleagues and students alike. He will be deeply missed by us.

We greatly appreciate the use of the "Wildfire Chronosequence Project" plots at Warra that have been set up by P. Turner and co-workers. Julia Sohn and Eva Hilbig received a Warra small projects grant from Forestry Tasmania (FT), who also provided technical and organisational support. We are grateful for field assistance by Craig Airey (FT) and many others.

\section{REFERENCES}

Bauhus, J., Puettmann, K. \& Messier, C. 2009: Silviculture for old-growth attributes. Forest Ecology and Management 258: 525-537.

Brown, M.J., Elliott, H.J. \& Hickey, J.E. 2001: An overview of the Warra Long-Term Ecological Research Site. Tasforests 13: $1-8$. 
Carmona, M.R., Armesto, G.G., Aravena, J.C. \& Perez, C.A. 2002: Coarse woody debris biomass in successional and primary temperate rainforests in Chiloe Island, Chile. Forest Ecology and Management 164: 267-275.

Chojnacky, D.C. \& Heath, L.S. 2002: Estimating down deadwood from FIA forest inventory variables in Maine. Environmental Pollution 116: 25-30.

Franklin, J.F., Spies, T.A., VanPelt, R., Carey, A.B., Thornburgh, D.A., Berg, D.R., Lindenmayer, D.B., Harmon, M.E., Keeton, W.S., Shaw, D.C., Bible, K. \& Chen, J. 2002: Disturbances and structural development of natural forest ecosystems with silvicultural implications using Douglasfir forests as an example. Forest Ecology and Management 155: 399-423.

Gough, C.M., Vogel, C. S., Kazanski, C., Nagel, L., Flower, C.E. \& Curtis, P. S. 2007: Coarse woody debris and the carbon balance of a north temperate forest. Forest Ecology and Management 244: 60-67.

Grove, S.J. 2001: Extent and composition of dead wood in Australian lowland tropical rainforest with different management histories. Forest Ecology and Management 154: 35-53.

Grove, S.J. 2002: Saproxylic insect ecology and the sustainable management of forests. Annual Review of Ecology and Systematics 33: 1-23.

Grove, S.J., Stamm, L. \& Barry, C. 2009: Log decomposition rates in Tasmanian Eucalyptus obliqua determined using an indirect chronosequence approach. Forest Ecology and Management 258: 389-397.

Harmon, M.E., Franklin, J.F., Swanson, F.J., Sollins, P., Gregory, S.V., Lattin, J.D., Anderson, N.H., Cline, S.P., Aumen, N.G., Lienkaemper, G.W., Cromack, K.J. \& Cummins, K.W. 1986: Ecology of coarse woody debris in temperate ecosystems. Advances in Ecological Research 15: 133-302.

Harmon, M.E.\& Sexton, J. 1996: Guidelines for measurements of woody detritus in forest ecosystems. Publication No 20. US Long-Term Ecological Research Network Office. University of Washington, Washington: 73 pp.

Harmon, M.E. in press: Woody detritus mass and its contribution to carbon dynamics of old-growth forests: The temporal context. In Wirth, C. Gleixner, G. \& Heimann, M. (eds) Old-growth forests: Function, fate and value. Ecological Studies, Springer New York, Berlin, Heidelberg: 159-190.

Hickey, J.E., Kostoglou, P. \& Sargison, G.J. 2000: Tasmania’s tallest trees. Tasforests 12: 105-122.

Hunter, M.L. 1994: Dying, dead, and down trees. In Hunter M.L. Jr (ed.) Managing Forests for Biological Diversity. New Jersey, USA: Prentice Hall: pp. 157-180.

Karjalainen, L. \& Kuuluvainen, T. 2002: Amount and Diversity of Coarse Woody Debris within a Boreal Forest Landscape Dominated by Pinus sylvestris in Vienan salo Wilderness, Eastern Fennoscandia. Silva Fennica 36(1): 147-167.

Keeton, W.S. 2006: Managing for late-successional/old-growth forest characteristics in northern hardwood-conifer forests. Forest Ecology and Management 235: 129-142.

Kennedy, R.S.H. \& Spies, T.A. 2007: An assessment of dead wood patterns and their relationship with biophysical characteristics in two landscapes with different disturbance histories in coastal Oregon, USA. Canadian Journal of Forest Research 47: 940-956.

Kirby, K. J., Reid, C. M., Thomas, R. C. \& Goldsmith, F. B. 1998: Preliminary estimates of fallen dead wood and standing dead trees in managed and unmanaged forests in Britain. Journal of Applied Ecology 35(1): 148-155.

Krebs, C.J. 1989: Ecological methodology. New York: Harper Collins Publishers, Inc.: 654 pp.

Lindenmayer, D.B. \& Franklin, J.F. 2002: Conserving forest biodiversity. A comprehensive multiscaled approach. Island Press, Place of publication: $351 \mathrm{pp}$.

Lindenmayer D.B., Franklin J.F. \& Fischer, J. 2006: General management principles and a checklist of strategies to guide forest biodiversity conservation. Biological Conservation 131: 433-445.

McElhinny, C., Gibbons, P. \& Brack, C. 2006: An objective and quantitative methodology for constructing an index of stand complexity. Forest Ecology and Management 235: 54-71.

McKenny, H.J.A. \& Kirkpatrick, J.B. 1999: The role of fallen logs in the regeneration of tree species in Tasmanian mixed forest. Australian Journal of Botany 47: 745-753.

Naesset, E. 2007: Airborne laser scanning as a method in operational forest inventory: Status of accuracy assessments accomplished in Scandinavia. Scandinavian Journal of Forest Research 22(5): 433-442.

Pedlar, J.H., Pearce, J.L., Venier, L.A. \& McKenney, D.W. 2002 : Coarse woody debris in relation to disturbance and forest type in boreal Canada. Forest Ecology and Management 158: 189-194.

Pesonen, A., Maltamo, M., Eerikainen, K. \& Packalen, P. 2008 : Airborne laser scanning-based prediction of coarse woody debris volumes in a conservation area. Forest Ecology and Management 255: 3288-3296.

Private Forests Tasmania 2001: Farm Forestry Toolbox, version 4.0. Private Forests Tasmania, Hobart.

Ranius, T., Kindvall, O., Kruys, N. \& Jonsson, B.G. 2003: Modelling dead wood in Norway spruce stands subject to different management regimes. Forest Ecology and Managementage 182: 13-29.

Ranius, T. \& Kindvall, O. 2004: Modelling the amount of coarse woody debris produced by the new biodiversity-oriented silvicultural practices in Sweden. Biological Conservation 119: $51-59$.

Schlegel, B.C. \& Donoso, P.J. 2008: Effects of forest type and stand structure on coarse woody debris in old-growth rainforests in the Valdivian Andes, south-central Chile. Forest Ecology and Management 255: 1906-1914.

Siitonen, J. 2001: Forest management, coarse woody debris and saproxylic organisms: Fennoscandian boreal forests as an example. Ecological Bulletins 49:11-42.

Spies, T.A., Franklin, J.F. \& Thomas, T.B. 1988: Coarse woody debris in Douglas-fir forests of western Oregon and Washington. Ecology 69: 1689-1702.

Stamm, L. 2006. Measuring and modelling coarse woody debris in tall wet eucalypt forest in Southern Tasmania. Unpublished Honours Thesis, University of Tasmania, Hobart.

Stewart, G.H. \& Burrows L.E. 1994: Coarse woody debris in old-growth temperate beech (Nothofagus) forests of New Zealand. Canadian Journal of Forest Research 24: 1989-1996.

Turner, P., Airey, C. \& Grove, S.J. 2007: Wildfire chronosequence project establishment report. Division of Forest Research and development. Forestry Tasmania, Hobart: $71 \mathrm{pp}$.

Van Wagner, C.E. 1968: The line intersect method for forest fuel sampling. Forest Science 14: 20-26.

Warren, W.G. \& Olsen, P.F. 1964: A line intersect technique for assessing logging waste. Forest Science 10: 267-276.

Wells, P. \& Hickey, J. 2005: Wet sclerophyll, mixed and swamp forest. In Reid, B.R., Hill, R.S., Brown, M.J. \& Hovenden, M.J. (eds). Vegetation of Tasmania. Commonwealth of Australia: 224-241.

Williams, M.R. \& Faunt, K. 1997: Factors affecting the abundance of hollows in logs in jarrah forest of south-western Australia. Forest Ecology and Management 95: 153-60.

Woldendorp, G., Keenan, R.J., Barry, S. \& Spencer, R.D. 2004: Analysis of sampling methods for coarse woody debris. Forest Ecology and Management 198: 133-148.

Woldendorp, G. \& Keenan, R.J. 2005: Coarse woody debris in Australian forest ecosystems: a review. Austral Ecology 30: $834-843$.

(accepted 1 October 2013) 
